\title{
Between Rationality and Uncertainty: Exploring the Finest Strategy to Manage Disaster Governance and Budgetary Perspective
}

\author{
Bambang Supriyono ${ }^{1}$, Oscar Radyan Danar ${ }^{2}$ \\ 1, 2 Faculty of Administrative Science, University of Brawijaya, Mt. Haryono Street, Malang, East Java, Indonesia. \\ ${ }^{2}$ Corresponding Author: Oscar Radyan Danar
}

Article Info

Article History;

Received:

2021-07-03

Revised:

2021-09-28

Accepted:

2021-12-14

\begin{abstract}
A massive damage and loss of natural hazards occurred in Indonesia rising numerous questions about government's capacity to minimize disaster risk through appropriate disaster governance strategy. This article explores the strategy to manage the disaster and budgetary mechanism which is currently underpinned on rationalist principle. However, during the dynamic situation and high degree of uncertainty, the effectiveness and efficiency of the rationalist principle remains questionable. It has been supported by set of notorious consequences of disaster that has been undertaken by government in recent years. Therefore, by using qualitative approach, the research in this article has aimed to seek the performance's description and shortcomings of current strategy based on theoretical analysis and literature study. The finding of this study illustrates the vague mechanism particularly in terms of local disaster strategy, political decision making and flexibility to reimbursement mechanism. Finally, at the end of this article also gives specific recommendation for policymakers to give plenty space for current strategy to be more adaptive toward any turbulences in the future.
\end{abstract}

Keyword: Disaster Risk; Rationalist Strategy; Uncertainty; Decision Making.

DOI: https://doi.org/10.18196/jgpp.v9i1.12211

\section{INTRODUCTION}

The Asian financial crisis in 1997-1998 has become one of an alarming situation for many countries in the world. On this occasion, the quality of government for governing their country has been tested to minimize the impact of the crisis. Several countries with greater governance feature were tend to survive due to the financial contagion. However, the rest of them were still developing and motorized by limited capacity of government. In these developing countries, the impact of financial crisis has led the unstable situation occurred in economic and social sector. Moreover, in some countries the chaotic situation happened as the result of society's demand for better governance system. Under this circumstance, the government will face two major options as the exit tunnel from the crisis. Either they will stand with current system and rethink the viable solution from outside such as loosening fiscal rule with public debt from international organization or they will initiate the reform and rebuild the current system from the inside. 
Indonesia as one of developing nation has decided the later pathway with primary concern to conduct the administrative reform (Danar, Kusumasari, and Muluk, 2021). During the reform process, the main initiative is to transfer the authority from central to local government with fixed attribute or known as decentralization (Law No.22 of 1999). Thus, it can be inferred that decentralization is the major product of administrative reform in Indonesia. Few years later, after local government has performed decentralization, it also being equipped with local autonomy (Law No. 32 of 2004) as well as local budget (Law No.33 of 2004) which enable them to decide the best strategy and policy option for local region.

According to (Kirana, 2014) the decision to allow local government performing their own policy and strategy may resulting double edge of consequences. Either they will be able to maximize the regional potential or they will suffer from the failure for lack of capacity. In line with this matter, the central government then proposed the rationalist strategy as the motion that should be followed by local government units. This motion will act as the basic principle emanating general guidelines to set up planning strategy and policy options. Wilson (1992) conveyed that rationalist strategic management will ensure the institutional units to act as relevance as vision, mission, long-term planning, proposed indicators, as well as concrete goals. The impact of this motion has been proven by significant progress of development particularly in post reformation period which is become the exit tunnel for Indonesia to regain economic and social condition.

Despite the rationalist principle seems quite efficient for planning strategy in local government it still contains several drawbacks. In fact, several sectors will require a more flexible mechanism rather than well integrated plan with fixed attributes. One of prominent case to express this drawback is within disaster management budgetary mechanism. In Indonesia, the local budgetary policy is divided into three main channels, consist of local revenue, local expenditure, and local payment. Furthermore, the budget for disaster management is located in local expenditure channel with fixed amount called unexpected expenditure (Belanja Tidak Terduga/BTT) here in after will be called as BTT.

The sources of BTT come from remaining cumulative value of local revenue in previous years. In other words, the amount of BTT is highly dependent from the fiscal performance of local government which is uncertain. The local government with good fiscal performance in few years before will tend to have greater amount of BTT while the other local government with lower fiscal performance will always underwent the deficit in BTT amount. Therefore, it can be imagined when the disaster occurred in a region with deficit BTT amount, then it will lead to the lack of budget to manage disaster impact. In a more detailed look, lack of budget to manage disaster impact will prevent the stakeholder to maximize their capacity.

In Indonesia, the capacity to manage disaster should be a primary concern of government by considering high potential of disaster risk. It has been reported that more than 1.272 cases of disasters happened Indonesia (aside from COVID-19 pandemic) during 2020 to 2021. These disasters have caused significant impact including death, damage and losses as presented in table 1.

Table 1. Disaster Impact toward Human and Non - Human

\begin{tabular}{lccccccc}
\hline & \multicolumn{2}{c}{ Human } & \multicolumn{3}{c}{ Non-Human } \\
\hline Death & Injuries & Missing & $\begin{array}{c}\text { Suffer and } \\
\text { evacuate }\end{array}$ & Damage on housing & \multicolumn{2}{c}{$\begin{array}{c}\text { Damage on public } \\
\text { facilities }\end{array}$} \\
\hline 493 & 12.816 & 68 & 5.067 .692 & Slight & Heavy & Slight & Heavy \\
& & & & 96.645 & 14.506 & 345 & 1.365 \\
\hline
\end{tabular}

Source: Indonesian National Disaster Management Agency (2021)

The data presented in table 1 reflects the enormous impact of disaster in Indonesia, which is should be minimized by increasing the government's capacity. Since the budgetary aspect is one of crucial component to support the government capacity, then it is important to establish 
an efficient mechanism regarding current disaster management budgetary system (Danar, 2020).

Indeed, it cannot be neglected that the rationalist principle is derived from rational choice theory that is embedded from economics perspective, which is quite sensible if every decision will be underpinned in effectiveness and efficient principle (Cabantous and Gond, 2011). Several arguments of rationalist supporters may express their doubt if the rationalist strategy is failed to perform disaster management budgetary system, because it is directly related to the goal attainment with effective and efficient movement (Darwanto, 2012). It is not exaggerated for them to express their hesitation, because numerous evidence can be easily found that rationalist strategy has proven its correlation with shared vision, ideas, goals, including organizational performance. The series of these arguments seems successfully answered most of question and critique to adopt rationalist principle to set up disaster management budgetary system.

However, there is one other question regarding rational strategy has been proposed by uncertainty management's supporters such as Lane and Down (2010); Samisami et al (2015), or Gafni, Walter and Stephen (2013) that still left opened. It has been acknowledged that the rational principle will easily embrace any supporting attributes around organization to be converted into desired outcomes, but 'will it perform the same way for undesired outcome?'. Everyone understand that disasters are not classified as one of desired outcome of organization. Then the similar question can be asked for policy makers, 'will rational strategy performed effectively for disaster management budgetary system?' where the disaster is not one of desired outcome and resources allocation toward this undesired matter is not organization priority. In a more detailed discussion, the disaster even can be labelled as turbulence which is naturally associated with uncertain condition. Therefore, the decision-making process should consider the gap between certain and uncertain condition.

Samisami et al (2015) argues uncertainty is one of essential consideration on managing environmental based variables aside from any certain chances. In line with this argument, Naschold and Daley (2009) initiate to compare the difference of rationalist strategic management view and uncertainty's management view as illustrates in the following table 2 .

Table 2. Comparative attributes between rationalist strategic management and management of uncertainty

\begin{tabular}{lll}
\hline No & \multicolumn{1}{c}{ Rationalist Strategic Management } & \multicolumn{1}{c}{ Management of Uncertainty } \\
\hline 1 & Vision and Mission & No prior organization wide intention \\
\hline 2 & Long term plans & Generating new perspectives, taking risks \\
\hline 3 & Strategic milestones & Self-operated dynamic group \\
\hline 4 & Culture building & Developing multiple culture \\
\hline 5 & Incentive and control system & Create and support heterarchic support system \\
\hline
\end{tabular}

Source: Naschold and Daley (2009)

According to Naschold and Daley's description either rationalist strategic management or uncertainty's management seems has their own dimension. Furthermore, the dimension will bring certain variable that is reflect the characteristic of rationalist or uncertainty's management.

The comparative variable presented by Naschold and Daley (2009) may raise many extended questions including, is it possible for organization to adopt both of variable interchangeably? what is the best option should be undertaken by leader and in what kind of situation? Could this possible if one organization adopt both of principle on different sector? Answering these questions will generate a series of debate as it has been demonstrated within Drucker's article (1985) long time ago. Therefore, it will become a more viable solution if this article uses fairly contextual approach which capable to accommodate both perspectives.

In other theoretical view, Lane \& Down (2010) proposed a win-win alternative through the conceptual model of decision making by considering either certain or uncertain condition. 


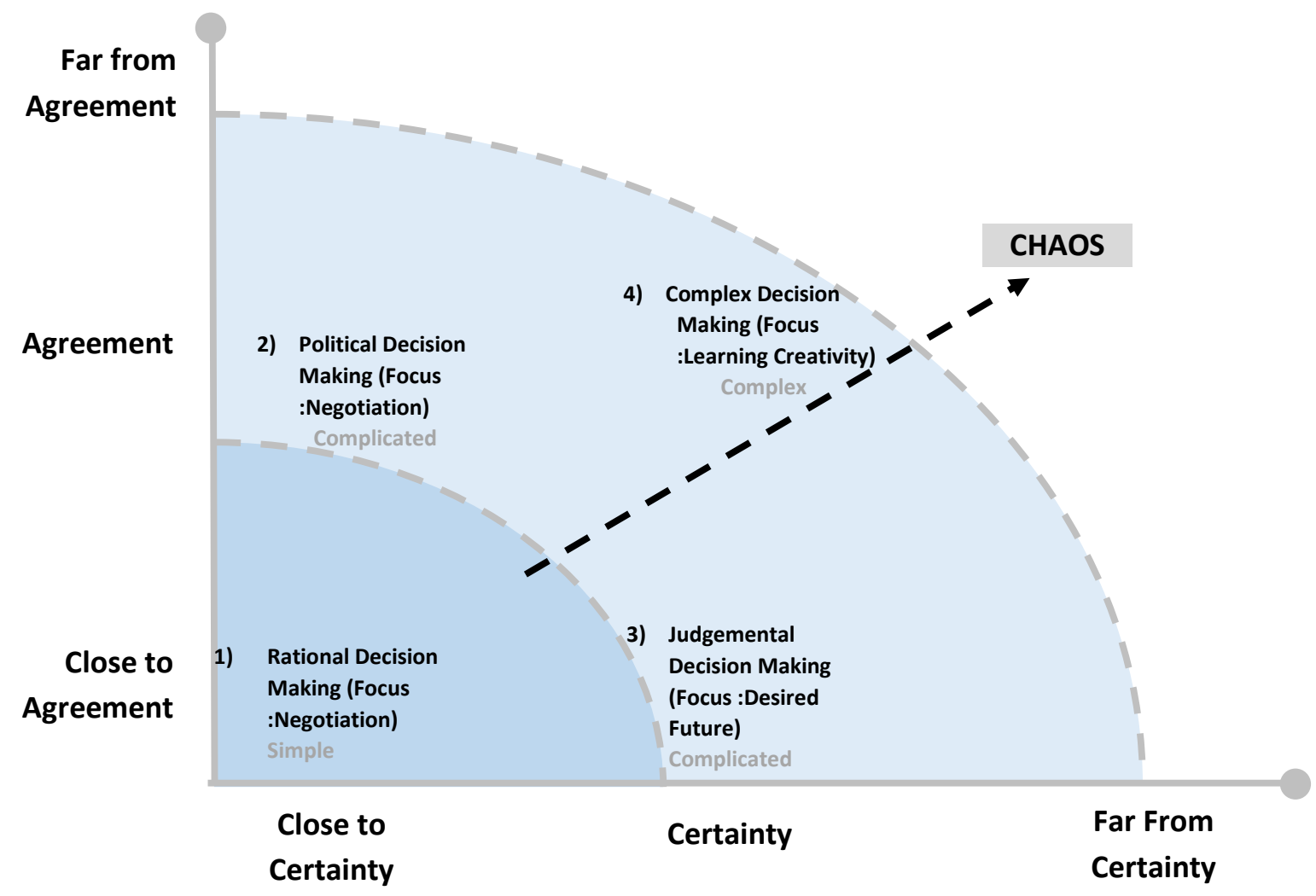

Figure.1 Conceptual model of decision-making process by considering certain and uncertain condition Source: Lane \& Down, 2010

In their proposal, Lane and Down (2010) convey if the future is essentially predictable then there is no need to give extra space under decision range and the rational strategy may suites to the best option. However, when the current situation deals with the high-risk turbulence such disaster the decision maker should give plenty space to cover uncertainty.

At least there are four models of decision making with different kind of focuses that are proposed by Lane and Down (2010).

1) Rational Decision Making: The rational decision making is recognized as one of the best options to set up planning strategy with high degree of certainty.

2) Political Decision Making: The political decision making is the next phase when a new trend has been occurred in which the current resources are failed to support the goal attainment. This condition is sometimes will deal with complicated agreement carrying extra need and interest. During this agreement the primary mission for organization's leader is to successfully deliver the strategic goals without sacrificing many extra resources including time.

3) Judgmental Decision Making: While political decision making related to the negotiation process because the existing resources insufficient to attain the organization's goal, the judgmental decision making is proposed the conversed ideas. The judgmental decision making has commonly undertaken by the leaders when they have good understanding toward technical consideration. In other words, although the current situation is out of previous plan but it is still under the track of certainty. Therefore,

4) Complex decision making: The final model is complex decision-making model or commonly stated as defensive decision-making model. Under the dynamic situation with high degree of uncertainty, several organizations sometimes may be hampered by complex situation preventing them to reach the determined purpose. Moreover, the chaotic situation may become particular threat toward the existence of organization itself. Under this circumstance, some leaders may think instead of reaching the previous goals as noted on its strategic plan with minimum chance of succeed, it is better to focus on 
organization's resilience and keep to stabilize the organization position. Therefore, the organization should undertake this experience as their valuable learning sources to set up better strategy in the future.

The series of this literature discussion is expected to be an effective tool to analyze the current situation of existing strategy and budgeting mechanism which is need to be improved Sagala, Wike and Danar (2021). This paper intended to explore the flaw in current strategy and budgeting mechanism as the consequence of rationalist principle which is ought to contain enough gap to accommodate uncertain situation with specific movement. The theoretical analysis is expected to give significant contribution by carrying the gap and transforming the current strategy and budgeting mechanism to be more flexible.

\section{RESEARCH METHOD}

This article uses descriptive research that is conducted through qualitative approach to explore the best strategy fulfilling the need of disaster governance budgetary system in Indonesia. This research undertaken qualitative approach due to its relevance to explore on why and how, particularly 'why the current strategy needs to be improved', 'what is the factors associate the problems', 'or how to improve the current strategy'. These motions will be elaborated into several questions and expected to be answered by specific key informants consist of policy makers from Pangandaran, Pasuruan and Pamekasan regency. The primary reason on why these regions has been chosen as the case study is because they are classified as the region with high-risk disaster potential that is above the national average $(143,64)$ with Pangandaran Regency $(164,30)$, Pasuruan Regency $(179,52)$, and Pamekasan Regency $(181,30)$.

The policy maker from these regions have been considered for their plenty experience to implement the strategy of disaster governance budgetary system in Indonesia. In addition, although this research uses qualitative approach to retrieve the main information, however the role of supporting evidence such as explanatory information or written literature are should not be ignored. The analysis of this research will be focused on seeking any contribution to improve existing strategy based on theoretical and literature perspective. Therefore, this research will also be strengthened by literature study examining the similar research, current literature as well as theoretical foundation to gain stronger exposure.

\section{RESULT AND DICUSSION}

\section{Current Implementation of Disaster Management Budgetary Mechanism and Existing Strategy}

The topic of disaster management in Indonesia has increasingly become one of government primary concern since 2004 after Tsunami wave has flattened Aceh Province. Since then, the national government of Indonesia has conducted a series of efforts intended to strengthen the capacity to tackle disaster risk. However, it is too difficult for embedding disaster management principle in many institutions across sector without settled regulation. Therefore, in 2007, the national government of Indonesia signed the law No.24 of 2007 providing general platform for disaster management policy. This law covers specific role of actors, responsibility, institutional structure, disaster management classification, budgeting, and control.

According to this law, the budgeting aspect for disaster management is become the shared responsibility between local and national government. While the allocation of budgeting resources is conducted by national government, local government, as well as local disaster management agency. This information has been confirmed by Mr. Luthfi as the head of planning division of Pasuruan's local disaster management agency. He stated 'there are two major allocations of disaster management budgeting, first is the fixed amount that is allocated trough $B P B D$ program and second is located on BTT which is only being allocated when a force majeure situation occurred' (Luthfi, L, Personal Interview, August 18, 2021). A similar tone of information also being stated by head of local disaster management agency in Pamekasan and Pangandaran. 
In addition to previous information, the interview in local disaster management agency of Pamekasan found additional interesting fact. It was stated by Mr. Nurul 'beside those two major allocations, we still have other options including ask for the future allocation from central government if there is emergency situation. Besides we may also use financial grants from central government if needed, or final option perhaps we can change the strategic plan in the next year'. Mr. Nurul adds, 'however there will be a long consideration from local legislative branch to sign this option, because many stakeholders sometimes have a wide range of opinion and it may prolonge the execution period, unless the impact of disaster may be harmful for the future' (Nurul, L, Personal Interview, August 18, 2021). In further research, the interview also found that although the primary budgeting sources comes from government but it is possible to consider other sources such as from private sector through corporate social responsibility or charitable action by society.

While in the case of disaster management strategy, this research found that different region has different strategy that is depending on regional situation and disaster potential. The term of strategy on this research refers to a strategic planning of local disaster management agency. Therefore, it may generate different result among local region as shown in the following table.

Table 3. Current strategies of disaster management in local government

\begin{tabular}{|c|c|c|c|c|}
\hline No. & $\begin{array}{c}\text { Strategic } \\
\text { Management } \\
\text { Component }\end{array}$ & Pangandaran Regency & Pamekasan Regency & Pasuruan Regency \\
\hline 1 & Main goals & $\begin{array}{l}\text { Increasing disaster } \\
\text { mitigation through local } \\
\text { development }\end{array}$ & $\begin{array}{l}\text { Minimizing disaster risk } \\
\text { in local region }\end{array}$ & Decreasing disaster impact \\
\hline 2 & $\begin{array}{l}\text { Strategic } \\
\text { Indicator }\end{array}$ & $\begin{array}{l}\text { Increasing on local capacity } \\
\text { to manage disaster }\end{array}$ & $\begin{array}{l}\text { Decreasing the number } \\
\text { of local disaster risk } \\
\text { index }\end{array}$ & $\begin{array}{l}\text { 1. Enhancing government capacity } \\
\text { to manage disaster impact } \\
\text { 2. Increase disaster preparedness } \\
\text { and local resilience }\end{array}$ \\
\hline 3 & $\begin{array}{l}\text { Strategic } \\
\text { policies }\end{array}$ & $\begin{array}{l}\text { 1.Massive socialization of } \\
\text { high disaster risk areas; } \\
\text { 2.Building community } \\
\text { resilience in village areas } \\
\text { (Destana); } \\
\text { 3. Efficient information } \\
\text { transfer regarding Early } \\
\text { Warning System (EWS). }\end{array}$ & $\begin{array}{l}\text { 1. Responsive action } \\
\text { toward high-risk region; } \\
\text { 2. Increasing structured } \\
\text { coordination among } \\
\text { stakeholder; } \\
\text { 3. Accelerating recovery } \\
\text { toward disaster-affected } \\
\text { areas; } \\
\text { 4. Strengthening } \\
\text { community resilience in } \\
\text { village areas (Destana) }\end{array}$ & $\begin{array}{l}\text { 1. Conducting socialization and } \\
\text { training for disaster risk } \\
\text { mitigation; } \\
\text { 2. Building community resilience } \\
\text { in village areas (Destana); } \\
\text { 3. Establishing systematic } \\
\text { information channel; } \\
\text { 4. Ensuring supply availability for } \\
\text { occurred disasters; } \\
\text { 5. Updating the current data of } \\
\text { recent disasters. }\end{array}$ \\
\hline 4 & $\begin{array}{l}\text { Specific } \\
\text { program }\end{array}$ & $\begin{array}{l}\text { 1.Early prevention program; } \\
\text { 2. Simulative preparedness } \\
\text { program; } \\
\text { 3. Disaster mitigation } \\
\text { program; }\end{array}$ & $\begin{array}{l}\text { 1. Early prevention } \\
\text { program } \\
\text { 2. Simulative } \\
\text { Preparedness for } \\
\text { Emergency Situation } \\
\text { Program; } \\
\text { 3. Rehabilitation and } \\
\text { reconstruction program }\end{array}$ & $\begin{array}{l}\text { 1.Early prevention program; } \\
\text { 2. Disaster emergency response } \\
\text { program; } \\
\text { 3. Rehabilitation and } \\
\text { reconstruction program. }\end{array}$ \\
\hline 5 & $\begin{array}{l}\text { Monitoring } \\
\text { and } \\
\text { evaluation }\end{array}$ & $\begin{array}{l}\text { Monitoring will be } \\
\text { conducted through the } \\
\text { annual evaluation of local } \\
\text { capacity index }\end{array}$ & $\begin{array}{l}\text { Monitoring will be } \\
\text { conducted through the } \\
\text { annual evaluation of } \\
\text { local capacity index }\end{array}$ & $\begin{array}{l}\text { Monitoring and evaluation will be } \\
\text { assessed based on: } \\
\text { 1. Number of active Destana; } \\
\text { 2. Number of disaster victim who } \\
\text { receive appropriate } \\
\text { accommodation; } \\
\text { These indicators will be assessed } \\
\text { every } 3 \text { months. }\end{array}$ \\
\hline
\end{tabular}

Source: Author (2021) 
The data presented in table 3 imply the current strategy written in planning paper of local disaster management agency. This strategy is commonly updated every year and adjusted toward the recent situation of disaster frequency. Furthermore, these strategies should be relevant either with current vision and mission of each region or with national strategy of disaster management that is issued by Indonesian National Disaster Management Agency. Therefore, the local disaster management will automatically gear as the implementation of local vision and mission and national disaster management.

\section{The Dilemma for an Adjustable Disaster Management Policy}

Unlike the disaster management policy in many monarch countries that are naturally highly coordinated from central government with minimum adjustment in grassroots level, the decentralization system and local autonomy in Indonesia have enabled local government to customize the local policy based on their local strategy. Under this circumstance, local government has actual role to adjust and customize the scenario. However, several prerequisites have providing strong border for local government movements, which is in one hand it is require relevancy with national disaster management strategy but in other hand it should be geared up with local development plan.

Although the data in table 3 is not actually designed for comparative perspective, but at least it may illustrate ample evidence to express the dilemma of public manager. For instance, it can be identified that main goals of strategic plan from Pamekasan and Pasuruan regency are quite resembled (reducing disaster risk and impacts). However, both of them certainly have several different policies such as accelerating recovery toward disaster affected areas and increasing structural coordination in Pamekasan regency. While in Pasuruan, the local government has specific policy to socialize and train disaster risk mitigation. Consequently, it will impede both of local governments to maximize their potential for managing disaster, because all policies in both regions are essential for each of them.

This phenomenon might be happened due to the vague form of existed strategy. It can be inferred if both of these local regions should adjust their goals as related as national strategy. However, when it comes to local policy and program, they have limitation because each of them is bounded with local development plan. Therefore, they cannot maximize disaster policy and program because certain local restriction. In fact, some regions may need to adopt similar policy and program from another although the program is not fairly correlated with local development plan.

\section{Exploring the Gap between Rational Strategic and Uncertainty for Disaster Management}

It is not a difficult consideration to recognize the main principle behind the local disaster management strategy in Indonesia. By examining the relevancies among main goals, strategic indicator, policy characteristic as well as specific program, it is clearly revealed that the current strategy has undertaken the rationalist principles. The data presented in table 3 illustrates how the attributes within disaster strategy in local level are connected each other. Therefore, the effort to analyze the gap between rational strategic management and uncertainty management should be commenced from the current strategy.

Phaup and Kirschner (2010) argues, some aspects of budgeting for disaster are intended to increase community welfare such as decreasing vulnerability or increasing capacity. Then it is quite reasonable if policy makers put the rationalist principles in the first settlement of local disaster management strategy. Even some uncertainty management supporters such as Lane and Down (2010) or Naschold and Daley (2009) is also expressed the similar perspectives. However, the strategy of disaster management needs to be able to adapt toward any turbulences in the future. Therefore, the existence of gap is required to accommodate uncertainty's movement in the future.

In fact, the finding of this research illustrates different way of justification, for example, the vague pattern of local disaster management strategy that difficult to accommodate policy change and program. The further consideration on this paper to respond this phenomenon is to suggest to put the first gap on the current strategy, such as converting control system to 
heterarchic system as conveyed by Naschold and Daley (2009). It means a local region may adopt some essential disaster policies and programs, although they are not quite related to development planning. Perhaps, these new policies and programs will not become the priority of implementation, but at least they will give particular contribution to minimize disaster risks.

Furthermore, the finding of this research also express the dilemma of public manager to deal with disaster management policy. It explains the exact problem within decision making process and leader's choice toward certain options. Lane and Down (2010) convey, within the normal and stable situation there will be no matters if a leader undertaken set of rational decisions with a light degree of uncertainty. It will ensure every decision to generate positive impact for achieving visions, missions, or long-term goals. Yet, the problem may appear if the degree of uncertainty has reached certain levels and become an obstacle to attain visions or long-term goals. In addition to this statement, Samisami (2015) suggest if policymaker should settle their awareness uncertainty level, particularly when it involved environmental based variables with high degree of uncertainty. Thus, the second gap will be positioned under decision making process to ensure all decision result will meet the requirement of current situation.

The conceptual model of decision-making process as noted in figure 1 may be settled as theoretical backbone to plant the second gap. It commences by following the rational decision when everything is under control of policy maker. The implementation of policy and program may be determined as the official plan settled by local disaster management agency. However, when disaster occurred and turn the controlled situation into the dire state. Then the policy maker may consider to use broader options such as political decision making or judgmental decision making.

The political decision making as conveyed by Lane and Down (2010) is expected to accelerate the negotiation process through new optimized agreement. According to the research findings, the negotiation process is one of vulnerable phase where the chance to meet desired outcome has commonly blurred by complicated situations in local parliament's nature. Under these circumstances, the local disaster management agency should demand a local regulation that is embedded by political decision-making principle to ensure the negotiation process to be conducted through effective and efficient mechanism.

While regarding the judgmental decision making, this paper suggest that policymaker should comprehensively understand the current situation within organization either in top managerial level or in operational level. Otherwise, the straight decision through judgmental decision making will instantly lead to the worst situation. The finding within this study also underlined the specific programs to maximize information transfer in Pangandaran and Pasuruan regency. However, the flow of information only being optimized under the grassroots level with main purposes of accelerating evacuation process. Lane and Down (2010) argues, better information transfer under the policy maker environment will generate greater decision making. Although it seems to be difficult for local mayor himself to understand all technical matter under disaster management, but specific effort to increase information transfer within government embodiment may be expected to minimize the asymmetric among policy maker. Therefore, the judgmental decision making may be undertaken with effective period.

\section{Specific Projection of Consequences toward the Disaster Management Budgetary Mechanism}

According to the information presented in previous section, it can be inferred that there are at least 5 (five) channels of disaster management budgeting mechanism based on government side. They are comprised of; 1) Annual budgeting which intended to cover daily operational and policy conducted local disaster management agency; 2) Unexpected expenditure budget (BTT); 3) Changing the future allocation plan, which is increasing extra allocation for disaster for next year; 4) Emergency budget from grants; and 5) Asking the future disaster allocation to reimbursement on current year without change the existing plan. Some of these channels might undergo significant change regarding the set of gaps within local disaster 
government strategy. Accordingly, the following table is intended to illustrate the specific projection of impact toward disaster management budgetary mechanism.

Table 4. Expected Impact on Current Strategy and Budgetary Mechanism

\begin{tabular}{|c|c|c|c|}
\hline $\begin{array}{l}\text { Existing condition } \\
\text { (Based on } \\
\text { findings) }\end{array}$ & $\begin{array}{l}\text { Specific Changes } \\
\text { from the gap } \\
\text { (Theoretical } \\
\text { suggestion) }\end{array}$ & $\begin{array}{c}\text { Expected Impact on } \\
\text { Strategy }\end{array}$ & $\begin{array}{c}\text { Expected Impact on } \\
\text { Budgetary Mechanism }\end{array}$ \\
\hline $\begin{array}{l}\text { Rigid strategy with } \\
\text { settled policy and } \\
\text { program }\end{array}$ & $\begin{array}{l}\text { Planted adjustable } \\
\text { policy and program }\end{array}$ & $\begin{array}{l}\text { The strategy may perform } \\
\text { its flexibility under } \\
\text { uncertain situation }\end{array}$ & $\begin{array}{l}\text { The flexibility is expected to } \\
\text { allow annual budgeting } \\
\text { allocation to cover more } \\
\text { appropriate needs. }\end{array}$ \\
\hline \multirow{4}{*}{$\begin{array}{l}\text { Single pattern of } \\
\text { decision-making } \\
\text { process with } \\
\text { rational principle }\end{array}$} & $\begin{array}{l}\text { Rational Decision } \\
\text { making }\end{array}$ & $\begin{array}{l}\text { Ensure all component within } \\
\text { disaster management } \\
\text { strategy are well performed }\end{array}$ & $\begin{array}{l}\text { Minimize the chance of } \\
\text { miss budget allocation }\end{array}$ \\
\hline & $\begin{array}{l}\text { Political Decision } \\
\text { making }\end{array}$ & $\begin{array}{l}\text { Optimized negotiation } \\
\text { through effective and } \\
\text { efficient mechanism }\end{array}$ & $\begin{array}{l}\text { Simplify the consensus } \\
\text { building to reimburse BTT } \\
\text { or emergency budget } \\
\text { grants }\end{array}$ \\
\hline & $\begin{array}{l}\text { Judgemental } \\
\text { decision making }\end{array}$ & $\begin{array}{l}\text { Enhance the decision } \\
\text { accuracy with greater } \\
\text { benefit on time and } \\
\text { resources }\end{array}$ & $\begin{array}{l}\text { Increase the effectiveness } \\
\text { and efficiency through } \\
\text { precise action }\end{array}$ \\
\hline & $\begin{array}{l}\text { Complex decision } \\
\text { making }\end{array}$ & $\begin{array}{l}\text { Significant lesson for better } \\
\text { future strategy }\end{array}$ & $\begin{array}{l}\text { Provide better exposure for } \\
\text { future budget allocation. }\end{array}$ \\
\hline
\end{tabular}

Source: Author

The illustration in table 4 reveals that embedding the gap within local disaster management strategy may be expected to contribute valuable changes toward the budgetary mechanism. However, the analysis of this research is still limited to the annual budget allocation, unexpected expenditure budget (BTT), and emergency budget grants. While the rest channels such as accelerating future reimbursement budget and changing future allocation plan are still beyond the scope of this study. Therefore, the future study is expected to cover both of mentioned channels to be optimized through different ways.

\section{CONCLUSION}

According to the comprehensive analysis from the inquiry's result indicates that the current strategy for disaster management still too vague and lack of capability to accommodate unexpected changes in the future. The rationalist principles adopted by government to organize the disaster management strategy have established rigid border for policymaker. Consequently, it may generate to lack of flexibility of disaster policy, program, and budgetary mechanism. The data from Pangandaran, Pasuruan, and Pamekasan Regency have provided sufficient illustration emanating the different policy and program under similar strategy. Therefore, it can be inferred that each of them has incomplete scope of policy implementation and limited range of disaster risk reduction programs. In fact, this phenomenon has commonly led to dilemmatic situation for public manager to generate appropriate decision.

In addition to this matter, this paper tries to suggest several adjustments toward strategic configuration by injecting uncertain principles to create specific gaps toward existing rationalist thought. The role of these gaps is essential because they will give plenty space for disaster management strategy to accommodate unpredictable phenomenon such as rapid change, or unexpected situation. The first gap is discussing about converting control system into hierarchic system, ensuring that any disaster related programs and policies in grassroots level 
weighting the priority for minimize disaster risks rather than channeling them into long term development plan. It means, the local region may have any disaster related programs that are not directly correlated with long term development plan, but these programs will contribute to minimize disaster risks.

Furthermore, the second gap will explore existing scheme for decision making process to ensure all decision result will meet the requirement of current situation. On this occasion, the analysis of this paper suggest that the policy maker should applies different approach for different situation, for instance rationalist approach during stable situation, political approach when the complicated negotiation process hampered, and judgmental approach when large resources are facing limited times. When the gaps have been planted within disaster management strategy, it cannot be neglected that they will create several changes including the financial sector. The budgeting mechanism is one of essential aspect that is closely related to the implementation of disaster management strategy, policy and program. Therefore, this paper also provides an illustration regarding the specific projection for disaster management budgetary mechanism as the direct impact of new strategy configuration.

\section{ACKNOWLEDGEMENT}

We would like to thank Mr. Tommy Anggriawan and Ms. Ria Fitriani who contributed to our manuscript. We also would like to thank the editorial team and reviewer for their comments and suggestions.

\section{REFERENCE}

Albrow, M. 2001. "Society as Social Diversity: The Challenge for Governance in the Global Age. In Governance in the $21^{\text {st }}$ Century. OECD.

Beck, U. 1992. The Risk Society: Toward a New Modernity. London: Sage Publication.

Beck, U. 2006. Reflexive Governance: Politics in the Global Risk Society. In Reflexive Governance for Sustainable Development, edited by J. VoB, D. Bauknecht, and R. Kemp, 31-56. Cheltenham: Edward Elgar Publishing.

Biermann, F., K. Abbott, S. Andresen, K. Bäckstrand, S. Bernstein, M. M. Betsill, H. Bulkeley, B. Cashore, et al. 2012. Navigating the Anthropocene: Improving Earth System Governance. Science 335 (6074): 1306-07.

Borins, S. 2001. The Challenge of Inovating in Government. The Pricewaterhouse Coopers Endowment for the Business of Government.

Cabantous, L., and Gond, J. P. 2011. Rational Decision Making as Performance Praxis: Explaining Rationality's Eternel Retour. Organization Science. Vol.22, No.3, 2011, pp.573-586.

Carolina, M. 2018. Kelemahan-Kelemahan Penanggulangan Bencana Alam di Indonesia. Buletin APBN. Pusat Kajian Anggaran Badan Keahlian DPR RI. Vol. III, Edisi 18, September 2018.

Danar, O. R. 2020. Disaster Governance: An Introduction (Sebuah Pengantar). Diva Press, Yogyarakta. Indonesia.

Danar, O. R., Kusumasari. B, and M. R. K. Muluk., 2021. From Phenomena to Implementation: Lesson and Challenges of Administrative Reform in Indonesia. Journal of Public Administration Issues, No.6, Special Issues II, PP.33-50.

Darwanto, H. 2012. Preliminary Examination of Existing Methodology for Allocating and Tracking National Government Budget for Disaster Risk Reduction (DRR) in Indonesia. UNISDR Research Paper. Url: https://www.unisdr.org/files/32377_32377indonesiadraft drrinvestmenttra.pdf (Retrieved at 17 May 2021)

Drucker, Peter D. 1999. Management Challenges for the 21 st Century. Harper Business. New York.

Fan, Y., et al. 2015. Disaster Response: An Examination of Resource Management in The Early Hour. Journal of Apllied Business and Economics Vol 17(2) 2015. 
Gafni, A., Walter, S., Stephen, B. 2013. Uncertainty and the Clear Decision Maker: Assessing and Managing the Risk of Undesirable Outcomes. Health Economics Journal Vol.22, No.11. 2013. Doi: $10.1002 /$ hec.2883

IRGC (International Risk Governance Council). 2005. Risk Governance: Towards an Integrative Approach. White Paper No. 1. Geneva: IRGC.

IRGC (International Risk Governance Council). 2008. An Introduction to the Risk Governance Framework. Geneva: IRGC.

IRGC (International Risk Governance Council). 2009. Risk Governance Deficits: An Analysis and Illustration of the Most Common Deficits in Risk Governance. Geneva: IRGC.

Kirana, G. 2014. Decentralization Dilemma in Indonesia: Does Decentralization breed Corruption? Independent Study Project Collection (ISP-Collection). Url: https://digitalcollections.sit.edu/isp_collection (Retrieved at 18 May 2021)

Lane, D. A., and Down, M. 2010. The art of managing leadership for the future: leadership turbulence. Management Decision Journal. Vol. 48, No.4, 2010. Pp 512-527.

Lavell, A. 2004. The Niño and Niña in Latin America: challenges for policy and practice. The 4th Annual IIASA-DPRI Forum.

Leeuw, F. L., RC Rist and RC Sonnichsen. 1994. Can Government Learn? Comparative Perspectives on Evaluation and Organizational Learning. New Brunswick, NJ: Transaction Publishers.

Loffler, E. 2003. "Governance and Government" in Tony Bovaird and Elke Loffler. Public Management and Governance. Routledge: London.

Luthfi, L. (2021, August 18). Personal interview.

Mulgan, G and Albury, D. 2003. Inovation in the Public Sector. Strategy Unit, Cabinet Office, October.

Naschold, F. M. and Daley, G. 2009. "The Strategic Management Challenge: Modernizing Local Government". In International Public Management Journal. Volume 2, Number 1.

Nurul. (2021, August 18). Personal interview.

Pfeffer, J. 1992. Managing with Power: Politics and Influence in Organizations. Boston, MA

Phaup, M., and Kirshner, C. 2010. Budgeting for Disasters: Focusing on the Good Times. OECD Journal on Budgeting, Vol.1, No.1, $2010 . \quad$ Url: https://www.oecd.org/gov/budgeting/48168599.pdf (Retrieved in 22 May 2021)

Renn, 0. 2008. Risk Governance: Coping with Uncertainty in a Complex World. London: Earthscan.

Renn, O., A. Klinke, \& M. van Asselt. 2011. Coping with Complexity, Uncertainty and Ambiguity in Risk Governance: A Synthesis. AMBIO 40 (2): 231-46.

Sagala, D. A., Wike, W., Danar, O. R. 2021. The Analysis of Disaster Risk Reduction Policy based on Socio Ecological Perspective. (Analisis Implementasi Kebijakan Pengurangan Risiko Bencana dalam Perspektif Sistem-Ekologi Sosial). Jurnal Ilmiah Administrasi Publik. Vol.7, No.1, 2021. Pp.1-9.

Samisami, F., Hosseini, S. H. K., Kordnaeij, A., and Azar, A. 2015. Managing Environmental Uncertainty: From Conceptual Review to Strategic Management Point of View. International Journal of Business and Management, Vol. 10, No.7, doi: 10.5539/ijbm.v10n7p215

Schneider, S. K. 1992. Governmental Response to Disasters: The Conflict Between Bureaucratic Procedures and Emergent Norms. Public Administration Review, Vol. 52, No. 2 (Mar-Apr., 1992), pp. 135-145.

Shi, P. 2012. On The Role of Government in Integrated Disaster Risk Governance-Based on Parctice in China. International Journal of Disaster Risk Science 3 (3): 139-146. doi:10.1007/s13753-012-0014-2. 
Smith, BC. 1985. Decentralization, The Territorial Dimension of the State. London: George Allen \& Unwin (Publishers) Ltd.

Wilson, I. 1992. Realizing the Power of Strategic Vision. Long Range Planning Journal, Vol. 25, No.5, pp.18-28. 